\title{
Para além da pulsão de morte: absurdo e revolta em Albert Camus
}

\author{
Beyond the death drive: absurd and revolt in Albert Camus
}

\author{
Thaís Cristina Alves Costa* \\ Evandro Barbosa*
}

\begin{abstract}
Resumo: O objetivo desse artigo é discutir a possibilidade de uma morte feliz, e, consequentemente, uma vida feliz a partir da interpretação de dois pilares filosóficos de obra de Albert Camus: o absurdo e a revolta. Por um lado, o absurdo diz respeito ao confronto da irracionalidade do mundo com o desejo de clareza e racionalidade que se encontra no homem, conduzindo-o a uma pulsão de morte. Por outro, a revolta está vinculada ao desejo inconsciente de uma moral que denominamos antiteísta ou moral de atitude por mover-se consciente no âmbito das ações concretas, nascidas do sentimento da absurdidade do mundo frente à morte e ao sofrimento, propiciando a pulsão de vida. Testaremos, ao final, a viabilidade dessa moral antiteísta promover uma morte feliz para quem sofre e uma vida feliz, apesar de todo sofrimento, para aquele que se depara com a morte do outro. Para isso, utilizaremos como fios condutores suas obras O Mito de Sísifo, A Peste e $O$ Homem Revoltado.
\end{abstract}

Palavras-chave: Morte; Felicidade; Absurdo; Revolta; Moral

Abstract: The purpose of this article is to discuss the possibility of a happy death, and consequently, a happy life based on the interpretation of Albert Camus' philosophical pillars, namely: absurd and revolt. For one hand, absurd concerns about the confrontation of the irrationality of the world with the desire for clarity and rationality that no man encounters. This is able to lead to the death drive. For the other hand, revolt is linked to the unconscious desire for a morality that is called anti-theistic morality or attitude morality for moving personally concrete actions, born out of the world's absurd feeling in the face of death and suffering, propitiating life drive. In the end, we will test the viability of this moral anti-theistic to promote a happy death for those who suffer and a happy life, despite all suffering, for those who are in front of the death of another. To do this, we will use the Albert Camus' books: The Myth of Sisyphus, The Plague, and The Rebel.

Keywords: Death; Hapiness; Absurd; Revolt; Moral

\section{Introdução}

Falar sobre o tema da morte é, antes de tudo, falar sobre a vida, seu sentido e sobre como ela deve ser vivida até findar. É em um mundo dilacerado pela guerra e atormentado pela miserabilidade da condição humana que o filósofo Albert Camus questiona se a vida

\footnotetext{
* Doutoranda em Filosofia na Universidade Federal de Pelotas, Pelotas, RS. E-mail: thais@email.unc.edu ORCID: https://orcid.org/0000-0002-1274-0431

${ }^{* *}$ Professor de Filosofia da Universidade Federal de Pelotas, Pelotas, RS. E-mail: costa.thaisalves@gmail.com ORCID: https://orcid.org/0000-0002-5695-3746
} 
vale ou não a pena ser vivida mesmo "quando não acreditamos nem em Deus nem na razão?”" Frente à consciência da transitoriedade da vida e a solidão da existência, Camus reafirma seu humanismo por meio de seus conceitos de absurdo e revolta em relação a nossa existência. Se, por um lado, o absurdo diz respeito ao confronto do homem com a irracionalidade do mundo movido pelo desejo de clareza e racionalidade, por outro, a revolta vincula-se ao desejo inconsciente das ações concretas nascidas do sentimento de absurdidade diante do mundo. Mais do que isso, essa revolta se manifesta como atitude diante da ausência de sentido de muitos atos que absorvem nossa existência. Enquanto o absurdo produz a pulsão de morte ${ }^{2}$, a revolta é capaz de conduzir à pulsão de vida ${ }^{3}$.

$\mathrm{Na}$ tentativa de discutir filosoficamente sobre o tema da morte e suas pulsões, analisaremos a ideia camusiana de que a existência humana pode ser feliz e com sentido mesmo diante da efemeridade de uma vivência de sofrimento e solidão, da certeza da mortalidade e da incompreensão da realidade sem que, para isso, precisemos recorrer a algum tipo de subterfúgio metafísico. Pelo contrário, Camus dirá que esses dois sentimentos de absurdo e revolta nos conduzirão a uma moral antiteísta (não ateísta) capaz de valorizar nossa condição humana e a pensar a morte como uma extensão da própria vida.

\section{Absurdo: $\mathrm{O}$ aparente não sentido da vida}

Na primeira página da obra $O$ Mito de Sísifo ${ }^{4}$ de Albert Camus, o leitor se depara com a inquietante afirmação: "só existe um problema filosófico realmente sério: o suicídio" 5 . Para Camus, perguntar se a vida vale ou não a pena ser vivida surge como uma questão ética e é condição para uma atitude perante ela. E sua "resposta” implica em confessar se a nossa vida vale ou não a pena, afinal "morrer por vontade própria supõe que

\footnotetext{
${ }^{1}$ CAMUS, O Mito de Sísifo, p.35.

${ }^{2}$ Os conceitos de pulsões de vida e morte desenvolvidas ao longo do texto possuem origens nas definições de pulsão de Freud. Para ele, a pulsão está situada na fronteira entre o mental e o somático, como o representante psíquico dos estímulos que se originam no corpo e alcança a mente. Especificamente, acerca da pulsão de morte (Todestrieb), ele a entende como uma tendência que levaria à eliminação da estimulação do organismo. O trabalho dessa pulsão objetivaria a descarga, a falta do novo, a falta de vida, isto é, a morte. Nesse caso, a pessoa não teria o desejo pela mudança, pois estaria fadada a buscar sempre estados anteriores. Sendo assim, a pulsão de morte é a pulsão em direção à própria morte e autodestruição. Confira Freud, Três ensaios sobre a teoria da sexualidade (1920).

${ }^{3}$ Há um duelo entre a pulsão de vida, Eros e a pulsão de morte, Thanatos, na teoria freudiana. Para ele, a pulsão de vida precisa encontrar formas de manter a vida ante a tendência mortífera da pulsão de morte. E para isso, a pulsão de morte deveria ser desviada para o exterior, evitando a morte e a autodestruição. Confira Freud, O Ego e o Id (1923).

${ }^{4}$ Originalmente publicada em língua francesa com o título Le Mythe de Sisyphe no ano de 1942.

${ }^{5}$ CAMUS, O Mito de Sísifo, p.17.
} 
se reconheceu, mesmo instintivamente, o caráter ridículo desse costume, a ausência de

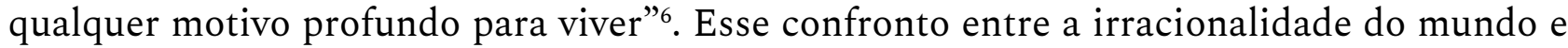
a nossa necessidade de clareza da realidade perpassará todas as obras camusianas, encontrando o seu desenvolvimento filosófico em $O$ Mito de Sísifo, considerada por muitos sua obra mais filosófica. Nela, o autor oferece subsídios teóricos para a noção do absurdo da existência humana através de figura emblemática de Sísifo que "os deuses condenaram a empurrar incessantemente uma rocha até o alto da montanha, de onde tornava a cair por seu próprio peso. Pensaram que não há castigo maior que o trabalho inútil e sem esperança”. Segundo ele,

Um mundo que se pode explicar mesmo que com raciocínios errôneos, é um mundo familiar. Mas num universo repentinamente privado de ilusões e de luzes, pelo contrário, o homem se sente um estrangeiro. É um exílio sem solução, porque está privado das lembranças de uma pátria perdida ou da esperança de uma terra prometida. Esse divórcio entre o homem e sua vida, o ator e seu cenário é propriamente o sentimento do absurdo ${ }^{8}$.

O absurdo diante da frugalidade da vida é que desconecta o homem do mundo, tornando-o um estrangeiro de sua própria existência. Isso por si só é um absurdo que consiste na contradição do mundo diante da razão humana. Em outras palavras, é o confronto da irracionalidade com o desejo insuperável de clareza, cujo apelo ressoa nas profundezas da dimensão humana. O sentimento de estranheza diante do mundo, o malestar que sentimos diante do "sem - sentido" é como um “abismo sem fim”, um confronto entre "o resultado do meu desejo de conhecer o mundo versus o que o mundo me apresenta

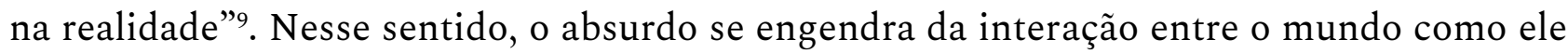
é e o eu, sendo a pulsão de morte uma sombra que nos acompanha para onde quer que vamos e que nos conduz em direção à morte e destruição

Simplesmente, num dia como outro qualquer, o sentimento de absurdo nos confronta. Diante de uma situação corriqueira como olhar-se no espelho, podemos nos perceber com diversos fios brancos. Ou, então, com sessenta anos de idade ao trocarmos uma lâmpada com vida útil de dez anos e percebemos que somente poderemos trocar essa lâmpada mais duas ou três vezes. É a realidade da possibilidade da morte que nos retira desse "sono", abrindo nossos olhos para o sentido da vida e a falta dele em muitas de nossas ações. Ora, de que valem economias, higiene e educação quando nos deparamos com nosso destino comum? Conforme Camus, "nenhuma moral, nenhum esforço são

\footnotetext{
${ }^{6}$ CAMUS, O Mito de Sísifo, p.19.

${ }^{7}$ CAMUS, O Mito de Sísifo, p.121.

${ }^{8}$ CAMUS, $O$ Mito de Sísifo, p. 20.

${ }^{9}$ CAMUS, O Mito de Sísifo, p.27.
} 
justificáveis 'a priori' diante das matemáticas sangrentas que ordenam nossa condição"10. O que se vê na realidade são gestos comuns às pessoas, como levantar pela manhã, ir trabalhar, almoçar, voltar para o trabalho, jantar, assistir televisão, atualizar o status na rede social e dormir para, no outro dia, repetir as mesmas ações.

Tal ritmo é repetido na segunda-feira, terça, quarta, quinta, sexta e sábado, consumindo toda a sua vida até a chegada da morte. Diante disso, qual seria o sentido de uma vida condenada à monotonia da repetitividade das ações? Reconhecendo a esterilidade da racionalidade metódica e organizadora do mundo moderno perante nossa condição de mortais, Camus expõe toda crueza da existência, afirmando que "o operário trabalha todos os dias de sua vida nas mesmas tarefas, e este destino não é menos absurdo. Mas só é trágico nos raros momentos em que se torna consciente” ${ }^{11}$. E, nesses breves momentos de lucidez, percebemos o absurdo da vida e sua eterna acompanhante: a pulsão de morte.

\section{Pulsão de morte}

Essa mesmice de ações consome totalmente nossas forças vitais e inevitavelmente nos conduz a essa pulsão de morte. Por isso, nas situações em que a morte é algo próximo, perguntas sobre o sentido de nossa existência surgem naturalmente: Será que a minha vida foi condenada à repetitividade de ações, as quais não possuíam qualquer sentido? Quando um dia um homem se pergunta por que se vive e se morre desta forma, o mundo se apresenta em sua absurdidade. Esse sentimento subjaz à estrutura interna do homem e se manifesta em todos nós, ínsito em cada um dos nossos gestos e até mesmo na ignorância que nos envolve a respeito de nosso destino. No segundo mais irradiante da nossa alegria ou na lenta deterioração do nosso tempo cotidiano, o absurdo evoca sempre, à maneira dum lusco-fusco interior, um inconfessado mal-estar, a meio caminho entre a lassidão e o medo, a surpresa e um invencível desprezo que sofre de não conseguir evadir-se de si mesmo $^{12}$. Mais do que isso, ele se evidencia na bipolaridade homem-mundo: não se trata de um sentimento de incomunicabilidade ou de exclusão entre ambos, mas de simples presença de duas realidades inconciliáveis, ininteligíveis e eternamente alheias.

Na coletividade, o absurdo desnuda a condição humana na insensatez praticada por quase todos nós, mesmo quando pensamos agir da forma mais natural possível. Na obra $A$ Peste, Camus comenta que a imprensa, o sacerdote, os guarda-costas, a multidão frenética

\footnotetext{
${ }^{10}$ CAMUS, O Mito de Sísifo, p.30.

${ }^{11}$ CAMUS, O Mito de Sísifo, p. 139.

${ }^{12}$ Segundo Camus, "Este lado elementar e definitivo da aventura é o conteúdo do sentimento absurdo. Sob a iluminação mortal desse destino, aparece a inutilidade. Nenhuma moral, nenhum esforço.” (CAMUS, O Mito de Sísifo, p. 30)
} 
não percebem ou fingem não perceber as ações sem sentido que ocorrem ${ }^{13}$. Assim como "político, não percebes profundamente a gravidade de seu gesto e vais assim pelos dias afora, acreditando piamente neste filantropismo asqueroso"14. A verdade é que tal agir tornou-se comum, dando-nos a impressão de estarmos agindo de acordo com regras insuspeitas de humanidade. Não se percebe plena sinceridade nas relações humanas: "em filosofia como em política, eu sou a favor de qualquer teoria que recuse a inocência ao homem, e a favor de toda a prática que o trate como culpado”15. Diante disso, estamos todos sós. Camus observa que as relações humanas foram corrompidas pela lógica perversa de uma racionalidade abstrata e impessoal que foi capaz de alienar os indivíduos para sua condição e a dos outros no mundo. Tal deficiência engendrou uma moral também perversa que sustenta a desfaçatez do comportamento humano, no qual, tudo é permitido, contando que eu seja preservado. Como ele afirma: "pode-se fazer a guerra neste mundo, macaquear o amor, torturar o semelhante, frequentar as colunas dos jornais ou, simplesmente, falar mal do vizinho enquanto se tricota" ${ }^{16}$. Esse é o absurdo da vida.

Entretanto, ao despertar para absurdidade em que se vive, o homem, segundo Camus, reconhece que não há como saber se este mundo tem um sentido que o ultrapassa e o conduz para uma pulsão de morte. Embora a dúvida nos persiga ao longo da vida são nas situações limites que tal indagação se manifesta com mais força e assume a forma de uma angústia existencial. Em situações como essas, “(...) o homem tem que lidar com as incertezas e inseguranças de um mundo que não sei se possui algum sentido" ${ }^{17}$, mas resta a nós apenas viver com aquilo que sabemos do mundo. E, diante desse fato, torna-se necessário decidir se a vida vale ou não a pena ser vivida.

É nesse sentido que o significado da morte, para nós, só pode ser dado pela pergunta sobre o sentido da vida. Por um lado, podemos optar pelo que Camus chama de “ignorância simulada”, que consiste em evitar pensar no absurdo através de um "sono" que não nos permite considerar o fato da morte, ou seja, é um fechar de olhos que nos permite viver o amanhã independentemente de considerarmos que iremos morrer. Para Camus, essa escolha funcionaria como uma espécie de suicídio expresso no ato em si ou no simples “deixa acontecer" de uma vida vazia e sem sentido. Nesse caso, o resultado nada animador se exprimiria em um desgosto pelo fim daquele que optou pela ignorância simulada: "no

\footnotetext{
${ }^{13} A$ peste de Camus é a verdadeira representação do mal, "a servidão, a injustiça e a mentira são pestes que estilhaçam a comunicação e impedem o diálogo. É por isso que devemos recusá-las.” (CAMUS, Essais, p.642) ${ }^{14}$ CAMUS, A Peste, p. 11.

${ }^{15}$ CAMUS, $A$ Peste, p. 90.

${ }^{16}$ CAMUS, $A$ Peste, p. 78.

${ }^{17}$ CAMUS, O Mito de Sísifo, p. 28. E mais, "Posso negar tudo desta parte de mim que vive de nostalgias incertas, menos esse desejo de unidade, esse apetite de resolver, essa exigência de clareza e de coesão.” (CAMUS, O Mito de Sísifo, p. 28)
} 
final de uma vida, a velhice volta em ondas de náusea"18. Tais ondas são experimentadas quando compreendemos a brevidade da vida pela proximidade da morte. Camus sugere, então, descartar toda forma de suicídio contra esse absurdo da existência humana e assumir aquilo que chama de atitude revoltada ${ }^{19}$. Nesse ponto, pulsões de morte e vida não são contrapontos, mas um enigma Janus-faced, ou seja, são faces de uma mesma moeda.

\section{Revoltar-se: pulsão de vida}

O sentimento de absurdidade conferirá à vida um novo e autêntico significado na medida em que despertará uma revolta que permitirá ao homem se situar em relação ao mundo. Uma constante na existência humana é o caráter transcendente que buscamos para nossa existência através da religião e outros ornamentos metafísicos, mas a relação com o próprio mundo ancora-se em um segundo plano como uma tensão homem-mundo. É nesta tensão, por meio da revolta, que constatamos que “(...) o absurdo da vida não pode ser um fim, mas apenas um começo. Esta é uma verdade da qual partiram todos os grandes espíritos. Não é esta descoberta que interessa, e sim as consequências e as regras de ação que se tira dela" ${ }^{20}$.

Alguém pode questionar, "quando foi que perdemos nossa compreensão sobre o nosso próprio mundo?”. A resposta é que, rejeitando o suicídio, já nos instalamos na revolta em relação ao absurdo e desvelamos o sentido disperso em meio ao não sentido. A revolta reconhece a insensatez da realidade que rejeita a morte e a solidão, trazendo a negação. Num primeiro momento, a revolta dirá não ao sofrimento, julgando-o inaceitável. Conforme Camus, "nada nem nenhuma doutrina poderia justificar o sofrimento de inocentes" ${ }^{21}$.

Ademais, a ação revoltada também é contrária a toda forma de violação e opressão ao outro, tal como em situações de injustiça e arbitrariedades. É importante compreender que o revoltado deseja a liberdade, mas também que se reconheça os limites da mesma. Afinal, como bem observa Camus, a revolta diante do mundo significa uma revolta diante da efemeridade da vida, mas não uma ausência de regra ou ordem.

\footnotetext{
${ }^{18}$ CAMUS, O Avesso e o Direito, p. 49.

${ }^{19}$ Merece destaque que o conceito de revolta não foi trabalhada na obra $O$ mito de Sísifo e, embora apareça em textos reunidos em Actuelles II, presente em Essais, somente vai adquirir uma fundamentação mais aprofundada na obra $O$ Homem Revoltado.

${ }^{20}$ CAMUS, A Inteligência e o Cadafalso e outros ensaios, p. 136.

${ }^{21} \mathrm{Na}$ obra $A$ Peste, Camus demonstrará através da figura de Paneloux a negação do sofrimento injustificável de uma inocente criança. Será na cabeceira do leito da criança moribunda que Paneloux murmura "com voz de sofrimento anônimo que não cessa: 'Meus Deus, salvai esta criança', todo o mundo o achou natural." (CAMUS, A Peste, p.238). Em seguida a criança morre.
} 
A questão camusiana é existencial e diz respeito ao próprio indivíduo em sua existência. Quando a morte nos alcança, a náusea surge de uma vida com sentido e não de uma vida sem limites de liberdade. Como veremos, a alteridade ou reconhecimento do outro faz parte dessa busca por sentido. Em nosso leito de morte, não é verdade que abraçamos aqueles que nos cercam e dão significado a nossa existência em detrimento à náusea de uma vida sem sentido?

Em seu extremo, a liberdade será injusta e oposta à ação revoltada. Em Calígula ${ }^{22}$, Camus sustenta o desdobramento desse excesso de liberdade frente à revolta. Conforme retrata, o imperador Calígula, confrontado pela repentina e absurda essência da morte, revolta-se contra valores morais, convenções e com a própria vida. Indignado, ele afirma: "de que me serve poder tão admirável se não posso mudar a ordem das coisas, se não posso fazer que o sol se pouse no leste, que o sofrimento decresça e que os homens não morram mais?”23. Decidido a partilhar sua revolta com todos que ainda não vivenciaram esse absurdo, ele escolhe a absoluta negação do homem e do mundo. Aproveitando-se de seu poder sem limites, escolhe prazerosamente matar, espalhando seu sentimento de absurdo a $\operatorname{todos}^{24}$. Será para evitar acontecimentos como esse que a liberdade exigirá o estabelecimento dos limites da ação humana: ausência de lei não é liberdade.

Para Camus, a tarefa de dar um sentido à liberdade é essencial e possui diversos desdobramentos. Num primeiro momento, ela aparecerá como amor a tudo aquilo que é terreno e terá extrema relevância para a concepção de moral antiteísta camusiana. Em seguida, ela será oposição às injustiças e opressões delimitando os seus limites em sociedade. O revoltado esforça-se para ter uma ação digna e justa afirmando o humano acima de tudo, pois o homem revoltado é capaz de se situar no mundo apesar do absurdo da morte e da solidão. Se pensarmos a revolta de um ponto de vista moral, ela assume um sentido ativo, na medida em que revela ao homem sua capacidade de viver uma vida com propósito, mesmo estando destinado à morte. ${ }^{6}$ Para Camus, somos capazes de viver, não obstante a certeza de nossa finitude, graças ao sentimento de revolta em relação à finitude. Agora, o homem elabora para si uma moral criadora de significados. Dessa forma, o

\footnotetext{
${ }^{22}$ Calígula mata com prazer e deboche: "Me escute bem imbecil. Se o Tesouro tem importância, então a vida humana não tem. Isto é claro. Todos aqueles que pensam como tu devem admitir este raciocínio e ter sua vida por nada visto que pensam que o dinheiro é tudo. Enquanto isto, eu decidi ser lógico e visto que tenho o poder, verás quanto esta lógica irá vos custar. Eu exterminarei os contraditores e as contradições. Se for preciso, começarei por ti” (CAMUS, Calígula, p.54). Além da peça, a obra $O$ Homem Revoltado dará o devido destaque para o conceito de revolta e sua relação com a liberdade humana, além das obras A Morte Feliz e Essais.

${ }^{23}$ CAMUS, Calígula, p. 56.

${ }^{24}$ Como ilustrada pela passagem: "Minha vontade é de mudar. Eu darei a este século o presente da igualdade. E quando tudo estiver aplainado, o impossível enfim sobre a terra, a lua nas minhas mãos, então, talvez, eu mesmo estarei transformado e o mundo comigo; então, enfim, os homens não morrerão e eles serão felizes" (CAMUS, Calígula, p. 54)
} 
revoltado busca um tipo de moral ou sagrado sem cair na desmedida de tentar justificar o sofrimento humano em nome dessa moral ou desse sagrado ${ }^{25}$. Quer dizer, uma ação que traga a pulsão de vida ou o "encontrar uma desmedida na medida"

Nesse movimento, é impossível ao homem aceitar toda realidade do jeito que é, mas também é impossível negá-la completamente. Como Camus apresentou com o protagonista d'O Estrangeiro ${ }^{27}$, Meursault denunciava sua estranheza em relação ao mundo ao se negar a aceitar padrões sociais impostos. Em uma demonstração paradigmática desse desapego, Meursault não demonstra quaisquer preocupações com as convenções sociais de casamento quando sua namorada pergunta se ele gostaria de se casar com ela. Segue a narrativa: "Marie veio buscar-me e perguntou se eu queria casar-me com ela. Disse que tanto fazia, mas que se ela queria poderíamos nos casar" ${ }^{28}$. Isso não significa que Mersault não goste de Maria, apenas que ele é indiferente ao regramento social de que viver feliz com alguém implique em casar-se com essa pessoa. De forma similar, Meursault também questiona o absurdo da vida quando não demonstra efusivamente sentimentos ou, aparentemente, não sofre com a morte da mãe, como quando lemos logo na primeira página: "Hoje mamãe morreu, ou talvez ontem, não sei bem. Recebi um telegrama do asilo: 'Mãe morta, enterro amanhã. Sinceros pêsames'. Isto não esclarece nada, talvez tenha sido ontem" ${ }^{29}$. Para aqueles que conhecem o desenrolar da obra, tamanha indiferença ao mundo foi determinante para a sua condenação à morte. Curiosamente, a negação aos princípios morais e religiosos ${ }^{30}$ recebe, esmagadoramente, maior reprovação da sociedade que o próprio assassinato como se o enquadramento social dele como ateu ou imoral fosse maior que o crime cometido.

De um ponto de vista teórico, Camus revolta-se com o absolutismo das regras do mundo. Como percebemos em sua obra, o homem revoltado é lúcido, pois experimenta o relativo como uma estratégia de preservação da vida. Como afirma Camus na obra Núpcias, só no relativo pode-se constituir uma regra moral, a qual se constrói “quando recusamos ao mundo qualquer espécie de significado [e] retrocedemos à supressão de todo

\footnotetext{
${ }^{25}$ Como em $A$ Peste quando o capelão entrou na cela do protagonista e perguntou: "Por que recusas minha visitas? - Respondi que não tinha fé. Quis saber se tinha a certeza e eu respondi que não valia a pena fazerme esta pergunta (...). Não tem então nenhuma esperança e consegue viver com o pensamento de que vai morrer inteiramente? - Sim - respondi. Disse que lamentava. Achava que tal atitude seria difícil de suportar” (CAMUS, A Peste, p. 240).

${ }^{26}$ CAMUS, O Homem Revoltado, p. 173.

${ }^{27}$ Obra ensaística que demonstra literariamente o absurdo e a revolta camusiana.

${ }^{28}$ CAMUS, $O$ Estrangeiro, p.46.

${ }^{29}$ CAMUS, O Estrangeiro, p. 87.

${ }^{30}$ Nas vésperas de sua morte, opta por não se render à religião. "Recusei-me, pela terceira vez, a receber o capelão. Não tenho nada a lhe dizer, não me apetece falar, tenho muito tempo para o ver. O que neste momento me interessa é fugir à engrenagem, saber se o inevitável pode ter uma saída.” (CAMUS, $O$ Estrangeiro, p. 87).
} 
julgamento de valor. (...) Escolhemos a sobrevivência a partir do instante em que nos deixamos morrer; portanto, reconhecemos à vida um valor pelo menos relativo" 31 . Sentir o valor da vida é ser entranhado por seu vigor que se renova, segundo Camus, pelo sol e mar. Só nele o homem pode construir uma regra moral; só nele o homem constrói para si uma ordem justa que tenha como princípio fundamental o valor inalienável da vida.

Em um segundo movimento, a revolta aceitaria essa realidade sem qualquer adereço metafísico que transcenda o terreno, oferecendo sentido a nossa vida e retirando o peso do mundo das nossas costas. Como o próprio Camus reconhece, "compreendi que no coração de minha revolta jazia um consentimento" ${ }^{32}$. Assim, a revolta será a afirmação do homem que, paradoxalmente, dará sentido ao que é absurdo - o sem - sentido do mundo - e escolherá a vida (e não o suicídio). Cabe salientar que, apesar de trazer clareza à realidade, a revolta não elimina o absurdo do mundo.

Essa compreensão do homem revoltado em sua existência também não implica em ateísmo. Afinal, rejeitar a ordem não implica na rejeição da existência de um possível ordenador. O revoltado é, sobretudo, um blasfemador ${ }^{33}$. Blasfemador porque não aceita e porque recusa a inumanidade da ordem. Mais do que negar a existência de um criador, a revolta e sua moral instituem o processo de uma inquisição existencial sobre Deus (é o movimento diametralmente oposto à inquisição religiosa que, em nome de Deus, condenava o homem em sua alteridade). Agora, Deus julgado é colocado no nível dos homens, os quais podem ser santos sem Deus ${ }^{34}$. Não cabe a Camus preocupar-se se Deus é bom ou cruel. Isso não faz diferença para ele, afinal sua preocupação recai sobre o humano. Nesse sentido, a recusa camusiana de Deus é uma recusa filosófica, não religiosa, uma vez que "a vida de um homem se realiza sem a ajuda de seu espírito, com seus recuos e seus avanços e, ao mesmo tempo, sua solidão e suas presenças" ${ }^{35}$. Dessa forma, o revoltado não se vê obrigado a chegar à inexistência de Deus, mas ele chegará, inevitavelmente, ao antiteísmo. O fenômeno da morte de Deus é, para Camus, a conclusão de uma filosofia revoltada.

$\mathrm{Na}$ medida em que perscruta o sentido da vida, o humanismo de Camus se opõe frontalmente à morte. Não podendo vencê-la em definitivo, desejamos, ao menos, não ver ela como a presença constante de uma sombra que se projeta na exposição do corpo à luz e

${ }^{31}$ CAMUS, Núpcias, p.116.

${ }^{32}$ CAMUS, A Morte Feliz, p.100.

33 Ao abordar a revolta metafísica, Camus trabalhará a ideia de blasfêmia dirigida a autores muito específicos, como Marquês de Sade, por exemplo. Por sua vez, a revolta metafísica é um protesto contra a condição ontológica do homem. Em outras palavras, a insurgência das pessoas contra sua condição e contra toda a criação. Para saber mais, confira: CAMUS, O Homem Revoltado (1951).

${ }^{34}$ CAMUS, A Peste, p. 222. Diz ainda, "colocando a história no trono de Deus caminhamos para teocracia. Não há mais consciência senão nas ruas, eis o decreto. Deliberadamente, o mundo foi amputado do que faz sua permanência: a natureza, o mar, a colina, a meditação das tardes” (CAMUS, Essais, p. 854).

${ }^{35}$ CAMUS, O Mito de Sísifo, p. 39. 
que ofusca a própria existência do corpo. Pensar nas pulsões de morte não significa resumir nossa existência à ideia de que a vida finda. Por isso, a ação revoltada não se projeta sobre o futuro; pelo contrário, nossa atitude é destinada ao mundo que sentimos tal qual uma ação de amor para com o presente sem preocupar-nos com as promessas do amanhã. Se queremos evitar as ondas de náusea da (in)existência em nosso leito de morte, a atitude revoltada requer o concreto e a condição da vida terrena como a essência da existência e o fundamento de uma moral de atitude. Mais do que isso, ela é o resultado da tensão entre o desejo de ser feliz e a consciência da morte e do abandono. Esta tensão faz com que o homem, na provisoriedade de sua existência, faça a opção em favor do bemviver, do amor e da paz.

Dessa forma, a revolta é a afirmação da condição do homem no mundo e de seu empenho em usufruir deste mundo e ser feliz ${ }^{36}$. O homem revoltado quer a paz. A sua revolta é contra tudo aquilo que minimiza a humanidade do homem como, v. e., as situações de morte e a injustiça. A revolta "nasce do espetáculo da desrazão diante de uma condição injusta e incompreensível (...) seu ímpeto cego reivindica a ordem no meio do caos e a unidade no próprio seio daquilo que foge e desaparece. A revolta clama, ela exige, ela quer que o escândalo termine" ${ }^{37}$. Nesse sentido, a revolta, por vezes, implica em criação (como a artística) e valores (genuinamente terrenos). Mesmo com a exaltação da experiência sensível e da natureza em Camus, isso não significa que a vida não exista fora da natureza. A revolta tem consequências no mundo humano, ela abre as vertentes da moral e da arte, abrindo espaço para a criação no mundo humano. Como fundamento da moral, a ação revoltada tem em seu bojo a consciência da condição humana de que jamais deve ser tornada absoluta. Impregnada de humanismo, essa ética genuinamente humana visa a alcançar o homem na concretude de sua existência ${ }^{38}$.

\section{A moral antiteísta camusiana}

Se, por um lado, o absurdo revelou a solidão do homem, a revolta, por sua vez, desnudou o quão o homem é também solidário. A revolta é criadora e, como será

\footnotetext{
36 Cabe salientar que a obra camusiana possui uma sequência. Logo em seus primeiros escritos Camus retratará o absurdo da vida tendo em sua obra $O$ Mito de Sísifo o auge de seu aprofundamento teórico. Posteriormente, na obra $O$ Homem Revoltado, a revolta surge como resposta a esse absurdo e sustentará a criação artística e a moral antiteísta como formas de escapar ao absurdo. Por fim, essa revolta criadora e valorativa conduzirá à morte feliz, que ultrapassará os problemas das pulsões de morte em prol da vida.

${ }^{37}$ Camus, O Homem Revoltado, p. 21.

${ }^{38}$ A tensão intrínseca à revolta não leva à paz dos cemitérios, mas a opção por uma difícil conduta seja no que concerne à convivência com os outros, seja à convivência do sujeito consigo mesmo. Recusando (ou consentindo) essa morte.
} 
apresentada por Camus em seus estudos mais avançados na obra O Homem Revoltado ${ }^{39}$, ela cria o principal valor para o homem como ser-no-mundo: a solidariedade. Esse sentimento de solidariedade, nascido da revolta, descobre efetivamente a presença do outro, com o qual passo a me simpatizar. O homem revoltado não é aquele que pretende conquistar algo que não possui, mas aquele que deseja ver respeitado o bem conquistado. Não deseja dominar, mas se afirmar como igual.

A revolta é a tradução da cumplicidade que se encontra no centro da condição humana. Ela se manifesta como diálogo, isto é, a vida opondo-se ao monólogo da injustiça. O homem revoltado se mostra livre e franco, contestando o poder que permite a um superior violar o limite do proibido, o outro: 'Longe de reivindicar uma independência geral, o revoltado quer que se reconheçam os limites da liberdade, lá onde se encontra em ser humano, o limite sendo o próprio poder da revolta deste ser ${ }^{30}$.

Antes da sensibilidade revoltada, a experiência da absurdidade afirmava que deveria viver, embora não dissesse que não deveria matar o outro. Nessa condição de absurdidade não apenas o suicídio é autorizado, mas também o assassinato, dada a insignificância do sentido da vida. Para Camus, o absurdo per si nos lança na indiferença em relação ao outro, ao passo que a revolta afirma o outro "a partir do momento em que se reconhece a impossibilidade da negação absoluta (...) a primeira coisa que não se pode negar é a vida de outrem" ${ }^{41}$. Entretanto, apenas a revolta salva na medida em que o homem revoltado é essencialmente simpático à condição do outro. A fidelidade universal do homem a sua própria condição de efemeridade é uma exigência de uma revolta em que simpatizo com o outro quando o compreendo efetivamente. Sendo, constitutivamente, uma descoberta da alteridade e da cumplicidade com o outro, "nada nos autoriza a dizer que se trata apenas dos direitos do indivíduo. Pelo contrário, parece efetivamente, pela solidariedade já assinalada, que se trata de uma consciência cada vez mais ampla que a espécie humana toma de si mesma ao longo de sua aventura" ${ }^{42}$.

Cabe, então, ao revoltado a tarefa de solidarizar-se. Ao reconhecermos o outro nós afirmamos a justiça e a felicidade, nos livrando do abandono. Esse é o sentido da vida. Apesar da provisoriedade de sua existência, optamos por viver bem e com os outros. Em nosso fim, queremos que nosso leito de morte seja cercado por aqueles que amamos como um ritual de despedida que celebra não a morte em si, mas a vida que a precedeu. A moral

\footnotetext{
${ }^{39}$ Ensaio filosófico de Albert Camus escrito em 1951, com o título original L'homme Révolté.

${ }^{40}$ CAMUS, O Homem Revoltado, p. 32.

${ }^{41}$ CAMUS, O Homem Revoltado, p. 417.

${ }^{42}$ CAMUS, O Homem Revoltado, p. 33.
} 
camusiana convoca, assim, o homem a viver a paz da confraternização - há uma "dignidade comum que não consigo degradar nem em mim nem nos outros" ${ }^{3}$.

A revolta antiteísta tem uma regra única: "aprender a viver e a morrer e, para ser homem, recusa-se a ser Deus" ${ }^{4}$. Não se trata de ser homem num reino divino, longe do sofrimento e das penúrias. Ser homem neste mundo é aceitar a pequenez de ser homem e de nada poder resolver diante de uma vida infinitamente maior do que ele mesmo. Todavia, mesmo sem poder tudo resolver, é possível ao homem ter forças para, em momentos raros e especiais, sentir que mesmo em meio à morte, à injúria, à infelicidade, à miséria, enfim, diante da vida como ela é, o sol continuará brilhando e a vida, pulsando.

É preciso que eu fique nu e, depois, mergulhe no mar e que, ainda perfumado de essências da terra, possa lavá-las nas águas desse mesmo mar, estreitando em meu corpo o abraço pelo qual suspiram, lábio a lábio, há tão longo tempo, a terra e o mar. Uma vez dentro d'água, é o sobressalto, a subida de uma viscosidade fria e opaca, depois o mergulho no zumbido dos ouvidos, o nariz a pingar e a boca amarga - o nado, os braços polidos de água, saídos do mar para se dourarem ao sol e de novos abaixados, numa torsão de todos os músculos, a corrida da água sobre meu corpo, a posse tumultuosa da onda pelas minhas pernas - e a ausência de horizonte. Na praia, é a queda na areia, abandonada ao mundo, uma vez mais de volta a meu peso de carne e osso, embrutecido de sol, lançando de longe em longe um olhar para meus braços, onde as poças de pele seca deixam a descoberto, à medida que a água escorre, a penugem loura e a poeira de $\mathrm{sal}^{45}$.

Em Camus, vislumbramos a possibilidade de uma sensibilidade feliz. Tudo o que não seja sol, mar, amor, céu azul e terra, não existem verdadeiramente: fora do sol, dos beijos e dos perfumes selvagens, tudo nos parece fúti ${ }^{46}$. O mundo é do tamanho da minha existência, nada me leva além dele: é tudo o que temos. A sensibilidade não nos permite buscar mais do que o mundo. Há no homem um desejo de ser feliz e este se oferece no espetáculo do mundo e na interação com a natureza. Nesse momento, a alteridade do outro se transforma em objeto de amor porque se confunde com o próprio mundo. E essa sensibilidade da felicidade nos revela que o único apelo permitido é o da natureza e o seu esplendor; nenhum absoluto nos chama para fora do mundo. Diante do transitório, é

\footnotetext{
${ }^{43}$ CAMUS, O Homem Revoltado, p. 450.

${ }^{44}$ CAMUS, O Homem Revoltado, p.350.

${ }^{45}$ CAMUS, Núpcias, p. 12.

${ }^{46}$ CAMUS, $A$ Morte Feliz, p.101. Em outro momento, ele assevera: "tratava-se anteriormente de saber se a vida devia ter um sentido para ser vivida. Agora parece, pelo contrário, que será tanto mais bem vivida quanto menos sentido tiver (...) Sentir o máximo possível sua vida, sua revolta, sua liberdade é viver o máximo possível. Onde reina a lucidez, a escala de valores torna-se inútil.” (CAMUS, O Mito de Sísifo, p. 65)
} 
necessário se afirmar nele. A moral antiteísta camusiana revela, então, a sensibilidade corpórea do ser que é intimamente ligado a outro por meio do sentimento do amor. Para isto vale nascer, viver e morrer. Morrer, mas não matar! Nada justifica a opressão, a injúria, a penúria ou o massacre. A reflexão ética proposta por Camus embasada na revolta nos leva à compreensão de que "a revolta não pode prescindir de um estranho amor" ${ }^{47}$. Estranho porque não nega a terra doente e todas as suas mazelas ao mesmo tempo em que aceita sua luz e sua alegria. Como ele mesmo afirma,

amo, perdidamente, esta vida e dela quero falar com liberdade: ela me dá orgulho da condição de homem. Entretanto, disseram-me: não há de se orgulhar. Sim, há de que me orgulhar: este sol, este mar, meu coração batendo de juventude, meu corpo com gosto de sal e o imenso horizonte onde a ternura e a glória se encontram no amarelo e azul ${ }^{48}$.

É na conquista de tudo isto que a força humana e todas as suas potencialidades se encontram.

\section{O mundo como existência: o exemplo de Rieux}

A moral camusiana nos convida, então, a compreender nossa vida a partir do modo como a valoramos e nos conduzimos no mundo. Com ela, percebemos que o advento da morte é parte da vida e não seu oposto. Camus explica que não é pela racionalização da morte que ela passa a ter significado ou, então, que nos tornamos desobrigados de morrer. Ronald Dworkin afirma que "o maior insulto à sacralidade da vida é a indiferença ou a preguiça diante de sua complexidade" ${ }^{49}$ retratando que a vida e a morte não podem ficar nas mãos de estranhos de avental branco e imaginando que o fim de nossa existência é tangenciável por questões meramente técnicas. Não é este o fim que desejamos.

Por isso, a única resposta plausível à pergunta sobre o sentido da vida e da morte é por intermédio de uma ética fundamentada na revolta diante de nossa finitude. Paradoxalmente, o homem revoltado compreende que não podemos negar a condição de finitude que nos oprime. Mesmo sabendo que jamais conseguiremos acabar com o sofrimento do mundo, ainda assim podemos encontrar sentido, valorizando a vida com felicidade terrena e a paz da solidariedade. A vida feliz não será alcançada pela racionalização ${ }^{50}$ de nossas relações, mas no contato direto com a natureza. Assim,

\footnotetext{
${ }^{47}$ CAMUS, O Homem Revoltado, p.348.

${ }^{48}$ CAMUS, $O$ Exílio e o Reino, p.58.

${ }^{49}$ Ibid., p. 343

${ }^{50} \mathrm{E}$, nós, "nos sufocamos entre pessoas que crêem ter absolutamente razão, seja em suas máquinas, seja em suas ideias. Para todos aqueles que não podem viver senão no diálogo e na amizade dos homens, este silêncio é o fim do mundo.” (CAMUS, Essais, p.332)
} 
conduzimos nossa vida em uma existência intensa com amor, beijos ardentes, amizade, mar e sol.

Talvez o maior exemplo dessa sensação se expresse em uma cena magnificamente descrita por Camus n'A Peste com o personagem Rieux. Quando este estava estafado física e psicologicamente diante de todo sofrimento, ele buscou auxílio junto à natureza:

sentou-se num banco perto de árvores poeirentas, enxugou o suor do rosto. Desejava gritar ainda para desatar o nó violento que lhe apertava o coração. O calor descia vagaroso entre os ramos das árvores. O céu azul da manhã vestia rápido uma fronha alvadia que tornava o ar mais sufocante. Rieux se deixou ficar no banco. Olhava os ramos, o céu, recobrando lentamente a respiração, vencendo pouco a pouco a fadiga (...) o mar soprava docemente ao pé dos grandes blocos do cais; surgiu, espesso como um veludo, flexível e manso como um animal. Chegaram, subiram nos rochedos. As águas subiam e desciam lentas. Essa respiração calma expunha e logo escondia reflexos e refletia aspectos oleosos na superfície. Diante deles estirava-se a noite, sem limites. Rieux sentia sobre os dedos a cara da pedra gasta e experimentava uma felicidade estranha ${ }^{51}$.

Nesse momento, Rieux entendeu o sentido da vida.

Nesse momento, uma vida e morte feliz se consumaria para Camus.

\section{Referências}

AMiOT AM, MATTÉi JF. Albert Camus et la philosophie. Paris: PUF, 1997.

BRISVILlE JC. Albert Camus: vida, pensamento e obra. Tradução Portuguesa por R. Guedes da Silva. Lisboa: Presencial, 1962.

BORRALHO ML. Camus. Porto: Rés, 1984.

CAMUS A. A Inteligência e o Cadafalso e outros ensaios. São Paulo: Record, 2000.

CAMUS A. A Morte Feliz. Rio de Janeiro: Record, 1997.

CAMUS A. A Peste. Rio de Janeiro: Record, 1999.

CAMUS A. A Queda. Rio de Janeiro: Record, 2002.

CAMUS A. Calígula. Lisboa: Edições Livros do Brasil, 1993

CAMUS A. Essais. Paris. Gallimard, 1965.

${ }^{51}$ CAMUS, $A$ Peste, p. 320. 
468 | Para além da pulsão de morte: absurdo e revolta em Albert Camus

CAMUS A. Les possedes: piece en trois parties adaptee du roman de Dostoievski. Paris: Gallimard, 1959.

CAMUS A. Núpcias. Rio de Janeiro: Nova Fronteira, 1979.

CAMUS A. O Avesso e o Direito. Rio de Janeiro: Record, 1995.

CAMUS A. O Estrangeiro. Rio de Janeiro: Record, 1996.

CAMUS A. O Exílio e o Reino. Rio de Janeiro: Record, 2001.

CAMUS A. O Homem Revoltado. 6. ed. Tradução Valerie Rumjanek. São Paulo: Record, 2003.

CAMUS A. O Mito de Sísifo. Tradução Ari Roitman e Paulina Wach. Rio de Janeiro: Record, 2007.

DWORKIN, Ronald. Life's Dominion: An Argument about Abortion, Euthanasia, and Individual Freedom. New York: Vintage Books, 1993

FREUD, S. Análise de uma fobia de um menino de cinco anos (o pequeno Hans). In J. Strachey, Edição Standard Brasileira das Obras Psicológicas Completas de Sigmund Freud(Vol. 10). Rio de Janeiro: Imago, 1996a

FREUD, S. A pulsão e seus destinos. In J. Strachey, Edição Standard Brasileira das Obras Psicológicas Completas de Sigmund Freud(Vol. 14). Rio de Janeiro: Imago, 1996b

FREUD, S. O id e o ego. In J. Strachey, Edição Standard Brasileira das Obras Psicológicas Completas de Sigmund Freud(Vol. 19). Rio de Janeiro: Imago, 1996c.

FREUD, S. Três ensaios sobre a teoria da sexualidade. In J. Strachey, Edição Standard Brasileira das Obras Psicológicas Completas de Sigmund Freud(Vol. 7). Rio de Janeiro: Imago, 1996d.

GUIMARÃES, CE. As dimensões do Homem: mundo, absurdo e revolta. São Paulo: Paz e Terra, 1971.

SPONVILlE, AC. Albert Camus de l'absurde à l'amour. Roubaix, 2001.

TODD, O. Albert Camus: uma vida. São Paulo: Record, 1998.

WEYNBERG, M. Albert Camus ou la mémoire des Origines. Le point philosophique. De Boeck Université, 1996. 